\title{
Bone Cancer Pathologic Primary Tumor TNM Finding v7
}

National Cancer Institute

\section{Source}

National Cancer Institute. Bone Cancer Pathologic Primary Tumor TNM Finding v7. NCI

Thesaurus. Code C88424.

A pathologic finding about one or more characteristics of bone cancer, following the rules of the TNM AJCC V7 classification system as they pertain to staging of the primary tumor. 